\title{
THE INTEGRATION OF AMERICAN IMMIGRANTS
}

\author{
Nathan Glazer*
}

I

One can make fine discriminations between the processes referred to by the words "Americanization," "adjustment," "assimilation," and "integration." But for the purposes of this article, all these words will be taken as equivalents, and "integration" will be favored as the least value-laden of the four. "Americanization," "adjustment," and "assimilation" suggest that something should happen to the immigrant in the United States, but that nothing, necessarily, should happen to the United States as a result of his presence. "Integration," drawn from the neutral terminology of the mathematical sciences, leaves the matter in abeyance: it suggests a more complex process than do the other three terms, and one in which, conceivably, the United States, as well as the immigrants, is changed.

But now, what do we refer to by "integration"? What do the defenders of immigration mean when they say the immigration groups have been "integrated" into American life, and what do the opponents of immigration mean when they say immigrant groups remain "unintegrated" in American life? What are the criteria of "integration"-which both sides assume to be desirable? And what are the indices of a proper integration? And, once having settled these matters, can we say that some immigrant groups "integrate" better than other immigrant groups?

The first step is clearly a clarification of the term "integration." As in so many cases where one word is used to cover many processes, I think it will be found that the clarification will enable us to dispose easily of many problems that come under the head of the "integration of immigrants" and permit us to focus on those problems that remain as truly significant.

At least three different matters are referred to by "integration." The first is that immigrants may create social problems -they may be poor and require relief, criminals and require more police and bigger prisons, insane and demand heavier expenditures for mental hospitals, illiterate and poorly educated, and, thus, put a strain on the school system, and so on. This is a fairly straightforward matter. Immigrants may be considered integrated when they require no greater public expense than do "other Americans." ("Other Americans" is itself an ambiguous term, for, when we discuss immigrant groups, we generally include their native-born children and very often their native-born grandchildren. These three generations

- B.S.S. 1944, College of the City of New York; A.M. I944, Univerity of Pennsylvania. Editor, Doubleday-Anchor Books. Formerly Associate Editor, Commentary. Co-author [with David Riesman and Reuel Denney], The Lonely Crowd (1950), and [with David Riesman] Fuces in the Crowd (1952); author, JUDAISM IN AMERICA (to be published 1956). 
include at least one-third of the American population. ${ }^{1}$ Yet, there is a legitimate category of "other Americans"-that large segment of the population-we cannot even guess whether it is one-half, or more or less than this-who no longer feel identified with any immigrant group, who consider themselves simply "Americans.")

The second distinct matter that is referred to by the term integration is that of the political behavior of immigrant groups. World War I, coming after fifteen years of very heavy immigration into this country, suddenly made people aware of the fact that immigrant groups in this country-even long-settled ones, like the Germans-might feel very passionately about the fate of their homelands, even though they had formally given up citizenship and become American citizens. World War II, coming fifteen years after mass immigration to this country had been shut off, and after a long period of time in which the depression and its problems had quite overshadowed any interest in the problems of immigrant groups, again demonstrated that many millions of Americans felt strongly about the nations they had left behind. In the meantime, millions of immigrants from Italy and eastern Europe who had come to this country between 1880 and 1924 and their children and grandchildren had become voters in many critical states. To the blocs of Irish and German voters who had been active on the American scene since the I850's were now added large and important blocs of Italian, Jewish, and Polish voters, and, in given areas, voters of Czech, South Slav, Rumanian, Hungarian, Finnish, and Greek origin were also important. In World War II and after, these blocs of voters remained as important in American politics as they had ever been. (We leave aside, for the moment, the question of how large a part of each of these groups was really swayed in its voting behavior by the interests of the home country - it is sufficient that politicians thought enough were so affected to take them seriously.) And it could legitimately be asked: does not the presence of large groups of immigrant origin hamper the development of a foreign policy determined solely by national interest? If the Jewish vote leads to a hasty recognition of Israel and the Polish vote to a more violent anti-Russian attitude than is actually required, do we not have real problems of "integration"?

These two are fairly concrete aspects of the problem of integration. We can discuss them on the basis of reasonably adequate statistics, considering advantages and disadvantages and coming to some kind of balance. It has often been done. We will do so briefly again in this article.

The third aspect of the integration of the immigrants is less easy to grasp. We may refer to it as cultural integration. To what extent do the immigrant groups form part of a single nation-not now in the political sense alone, but in the sense

\footnotetext{
1 The foreign-born and the children of the foreign-born formed $26.1 \%$ of the white population in I940, and, with the addition of the third generation, immigrants and the children and grandchildren of immigrants must easily have formed a third of the American white population. In 1920, the foreignborn and the children of foreign-born formed $34.5 \%$ of the white population. U. S. DEP'T OF COMmerce, Statistical Abstract of the United States 37 (1948).
} 
in which the people belonging to a nation form a kind of organism, a body, a unity, a whole?

What I have in mind can best be suggested by example. It is clear that England is English in culture and France is French in culture, aside from such tangible facts as that French and English are the languages of the two countries. The culture expresses itself in innumerable ways. Now, if persons of French descent formed only half the population of France, and persons of English descent only half the population of England-and the other half, worthy and patriotic citizens as they were, nevertheless, in many ways thought of themselves as belonging to some other cultural group-would not these countries have quite a different character?

It was a vision of this kind, I believe, that was in the minds of many Americans when they were greatly aroused, in the early twenties, by the cry that an influx of alien blood and lower races was about to change America radically and irrevocably. It was not, I believe, because they were convinced racists that they cut off the stream of immigration that had been part of American history so long. It was rather because, in the early twenties, race theory explained to them, in some intellectually satisfying way, just what it was they disliked and feared about the new immigration. And what they disliked so intensely about the new immigration was not that the immigrants were poor, sick, illiterate, radical, and unpatriotic (indeed, they were not, for the most part, any of these things, except poor-and not even poor for long), but that they were changing the United States. Their very presence, regardless of their social or civic qualities, changed the scene in which most Americans had grown up-or so it seemed to them. As a matter of fact, it was the growth of an industrial in place of a mercantile and agricultural America that was really changing the scene. It was an industrial revolution that was destroying the countryside, building the slums, enlarging the cities; but it did so with a steady stream of immigrants who differed both in appearance and culture from the long-settled Americans, and from the earlier immigrants too. It is when we discuss this third aspect of the integration of immigrants that passions are engaged, and real-and not easily resolvable-disputes arise.

\section{II}

As to the first two aspects of integration, the facts are clear. To consider the first aspect, namely that of social problems, of poverty, crime, education, health: it is clear that the European immigrants and their children form less of a problem than, for example, American Negroes, who are not immigrants; and it is further clear that the issue, in both cases, is not origins (for Negroes are not by nature doomed to be poor, unskilled laborers, criminals, sick, etc.), but social conditions. At times, different immigrant groups have loomed large as social problems: Irish, Italians, Puerto Ricans, and others. We now consider the particular prominence of any given group as a social problem as a temporary effect of special social conditions. We have seen the different groups succeed each other as social problems, and 
have seen groups of very different cultures supplying a disproportionate share of criminals, as each, in turn, moves into the slum areas of the big cities. It is only when we have a permanently depressed group-like the Negroes-that we have a group that permanently forms a social problem.

The facts that support this point of view may be found in many places. They are most conveniently summed up in the volume edited by William S. Bernard, American Immigration Policy. Let us sum up very brielly some of the evidence from this survey.

Occupation: Immigrants in the past have filled the less desirable economic positions. They have been heavy laborers, domestics, service workers. In time, they or their children have come to approximate the occupational distribution of the American population in general. Having settled in the more prosperous parts of the country, they are now likely to be somewhat more prosperous than the average American.

The one occupation in which we find markedly fewer immigrants and immigrants' children is in farming. But, since the farm population has been declining since $19 \mathrm{ro}^{2}{ }^{2}$ it is not surprising that relatively few immigrants have entered farming in recent decades. At an earlier stage in American history-when the great plains were being opened to farming, and before-it was immigrants (German, Norwegian, Swedish, Czech) who poured onto the land and established solid colonies of the foreign-born in rural country. In later years, when industry was expanding, new immigrants became laborers and semiskilled workers in heavy and light industry, in construction work, in mining, and formed solid colonies of the foreign-born in the big cities and the smaller industrial and mining towns. For both earlier and later immigrants, the processes of economic adjustment have remained the same; the results have been different because the economic situation of America was different. The later immigrants numbered as many farmers as the earlier ones; but they found opportunities in farming less attractive.

Indeed, that part of the farming population that is immigrant or of immigrant parentage (in 1940, about Io per cent) tend to be rather better farmers than the natives. The worst farmers in the country are probably the descendants of old-stock Americans in the southern Appalachians and other parts of the South; among the best were the Japanese of California-before they were uprooted-the Italian truck gardeners near the big eastern cities, and other immigrant groups. Immigrants have a higher proportion of farm owners and more valuable farms, on the average, than the native-born.

In this area of occupation and income, it is clear, immigrants and their children create no problem of integration. (Indeed, from the point of view of the old American, wondering where the next servant or gardener or janitor or unskilled laborer is coming from, they are perhaps too well integrated.) $)^{3}$

2 Sce A. J. Jaffe and Charles D. Stewart, Manpower Resources and Utilization i92 (i95i).

${ }^{3}$ See William S. Bernard (Ed.), American Immgration Polict i12-22 (I950) for all the facts in this section. 
Crime: Statistics in this area are notoriously difficult to use. The immigrants are now old, and it is not surprising that they form only a small percentage of the inmates of prisons-old people generally don't get into jail. Undoubtedly, immigrants' children contribute their proper share to American prisons, perhaps more. Certain immigrant groups-Jews, Chinese, Japanese-commit fewer crimes than the rest of the population. Other immigrant groups may commit more. Here, we do have a matter of varying cultural backgrounds which mean, for example, that people of certain groups more easily resort to violence, or are apt to get drunk, and so on. But this variation is true of the long-settled American population, too. It is not likely that immigrant groups have much to do with making the American crime rate what it is. ${ }^{4}$

Education and Intelligence: The foreign-born have slightly less education than the native-born. The difference between the educational attainments of their children and those of children of long-settled Americans must be even less and may even favor the children of immigrants. In IQ tests, immigrants and their children consistently have rated a bit below the children of native-born parents. The studies in this area are, however, old, and the influence of a foreign language spoken in the home would be adequate to explain these tiny differences. Certain immigrant groups, for example, the Jews, are better educated than the average American."

Health: Immigrants and their children, it appears, are less healthy and are more susceptible to mental disorders than children of native-born parents. (Again, there are groups where these differences are not observed.) The gap tends to narrow with the passing years, and, as in the case of the differences in IQ, it is reasonable to expect it to disappear entirely. ${ }^{6}$

We have reviewed immigrants as a social problem as of today, and it is clear they do not form much of a social problem; less of a problem, certainly, than the nonimmigrant Negroes, less of a problem, very likely, than the large poor-white population of the South (we exclude, of course, in our use of the term "social problem" the political and cultural problems we will discuss below). Thirty years ago, the matter was, of course, quite different. The foreign-born then formed a much higher proportion of the population, were concentrated in the slum areas of the great cities, and were highly visible as social problems. The incoming immigrants were very markedly different-in occupational abilities, education, health, and the like-from the native American population, and, in most respects, inferior. Since I924, with stringent control of incoming immigrants, this situation has been reversed, and incoming immigrants have often been superior in occupational skills, educational attainments, health, and so on, to the average American.7 Far from

\footnotetext{
'See id. at 122-25; on Jewish crime, see Goldberg, Jeus in the Police Records of Los Angeles, 1933-47, 5 Yivo Annual of Jewish Social Studies 266-91 (I950).

${ }^{5}$ See Bernard, op. cit. supra note 3, at I25-29; on Jewish education, see Glazer, Social Characteristics of American Jews, 1654-1954, 56 AM. Jewist Y. B. 28 (1955).

${ }^{6}$ See Bernard, op. cit. supra note 3 , at 129-35.

${ }^{7}$ See $i d$. at II5.
} 
creating problems, they are carefully selected to solve certain problems that arise in this country-as, for example, the need for certain specialized skills and for cheap, unskilled labor. We see, in retrospect (as many observers saw at the time), therefore, that the social problems created by immigrants thirty years ago were truly social problems, not racial problems, and could be expected to pass with the passage of time.

The poor we have always with us (though with certain variations of number and type), and today, the social-problems areas of our great cities are inhabited by Negroes, Puerto Ricans, and Mexicans. The same conditions breed the same problems. Sometimes, these problems are mitigated by certain cultural backgrounds; sometimes, they are exacerbated. Certainly, the policemen and teachers and social workers who now deal with the problem areas of American cities thirty years after mass immigration was shut off prefer the earlier situation. Not that there is any innate fault in Negroes and Puerto Ricans and Mexicans, but America finds it easier to deal with differences of culture than with differences of color. Since the colored groups have two strikes against them, the problems they create are, naturally, more severe than those created in the past by immigrant groups who expected to make the move out of the slums in one generation.

\section{III}

The political aspect of the integration of immigrant groups is a more complicated one, but again one in which we can come to fairly clear-cut conclusions. This issue first arose during World War I when the long-settled Americans observed with amazement the agitation of the immigrant groups. Those from Austria-Hungary and the Czarist empire saw in the war a possibility of freedom for the nations from which they came. The Germans rallied to the defense of the homeland, and the Irish, in their anti-English fury, were scarcely less pro-German than the Germans. As Randolph Bourne wrote in I9r6:

No reverberatory effect of the great war has caused American public opinion more solicitude than the failure of the "melting-pot." The discovery of diverse nationalistic feelings among our great alien population has come to most people as an intense shock. It has brought out the unpleasant inconsistencies of our traditional beliefs. We have had to watch hard-hearted old Brahmins virtuously indignant at the spectacle of the immigrant refusing to be melted, while they jeer at patriots like Mary Antin [a Russian-Jewish immigrant] who write about "our forefathers." We have had to listen to publicists who express themselves as stunned by the evidence of vigorous nationalistic and cultural movements in this country among Germans, Scandinavians, Bohemians and Poles, while in the same breath they insist that the alien shall be forcibly assimilated to that Anglo-Saxon tradition which they unquestioningly label "American."

A number of important themes are sounded in this quotation: what is of interest to us at the moment is that it was possible for a young radical of the time to see the nation-wide debate over neutrality as, in part, one between Anglo-Saxons and

\footnotetext{
${ }^{8}$ Randolph Bourne, A Histort of a Literary Radical and Other Essays 266 (1920).
} 
Germans. At that time, the Germans and their allies formed no insignificant part of the population. The German element in the United States, it was estimated from the data of the 1920 and earlier censuses, formed, in $x 920$, I6 per cent of the nativewhite population, the Irish another II per cent, the Scandinavians-many of whom tended to identify themselves with the German element among whom they lived ${ }^{0}$ another 4 per cent-and these three elements, leaving aside the immigrants from Austria-Hungary who supported rather than opposed the Dual Monarchy, formed close to a third of the native-white population of the United States. Descendants of immigrants from Great Britain formed only $4 \mathrm{I}$ per cent of the native-white population..$^{10}$

These facts, while interesting in themselves, and taken apparently with some interest by the German Government, turned out to be irrelevant when the chips were down, and this is the most decisive point to be made in considering the political integration of immigrant groups.

The immigrant groups in this country were not national minorities. They did not occupy stretches of territory in which they were unique national elements and in which their culture and language dominated. They had come, overwhelmingly, as individuals, settled as individuals, and if, on occasion, counties or even states happened to be dominated demographically by representatives of a single group, there were always enough members of other groups to check the development of national minority consciousness. This had happened, for the most part, quite accidentally-native Americans had no "divide and rule" ideology whereby the immigrants were to be spread around the country, so that the one-sixth of Germans, for example, could dominate not a single state. At one point, it is true, a conscious decision was made by Congress not to sell large tracts of land to a group that wished to settle them solidly with Irish; the decision was made to sell the national lands only to individuals. But in any case, whatever the views of occasional German ideologues, who dreamed of creating German nations on the free soil of America, the German immigrants came as individuals or small family groups, choosing their own land, and ready to be influenced by the same currents that influenced other Americans. ${ }^{11}$

When America entered the war against Germany, there was not the slightest hint of resistance or opposition from the German population. The resistance of the left wing of the Socialist party (which included, it is true, many Germans-but in this case, they acted more as Socialists than as Germans) was far more intense.

And similarly in World War II. Once again, immigrant passions were aroused, "congresses" were formed, money was raised, the various threatened and invaded homelands were supported; but when the war came, all ceased, and Germans and Italians were as dependable Americans soldiers as those of any other ethnic groups.

\footnotetext{
${ }^{9}$ See Samuei Lubeli, The Future of Amerucan Politics 135 (1952).

${ }^{10}$ See Kiser, Cultural Pluralism, 262 Annals r19 (I949).

${ }^{11}$ See Glazer, Ethnic Groups in Ametica, in Morroe Berger (Ed.), Freedom and Contmol in MODERN SOCIETY r60-64 (I954).
} 
And, indeed, the Japanese were as dependable too, when they were permitted to fight; it is notorious that the shameful decision whereby they were removed from the Pacific Coast was the result of anti-Japanese prejudice, and not of any objective danger of disloyalty. Once again, the disloyal were not those who defended their homelands against American foreign policy, but those who were ideologically opposed to this war-in this case, not the Socialists, but those influenced by Fascism and anti-Semitism.

When it comes to the question of loyalty in wartime, there is no problem of dual loyalty. Millions of Americans have fought under the American flag against their own homelands and the homelands of their parents and grandparents. We take this fact for granted, but it is one of the most remarkable in American history.

However, this is not the whole story; for, the single-minded loyalty of immigrant groups in wartime contrasts with the violence with which they defend the interests of their homelands in peacetime, and even in wartime, if those interests do not conflict with those of the United States. The Irish hatred of England has played as great a role in creating difficulties between this country and England as any objective conflict of interests between us. ${ }^{12}$ The vigorousness of Jewish lobbying for a Jewish state in Palestine has been referred to in a number of wartime diaries, ${ }^{13}$ and it has been pointed out that it endangered what were conceived to be American interests. And much the same might be said of other national groups.

Studies of the voting of ethnic groups have shown how, at times of crisis, identification with the homeland or the nation overrides what are generally considered good, old-fashioned American reasons for deciding one's vote-that is, personal self-interest. Consider, for example, the radical break against Roosevelt and for Wilkie (of German descent, it must be recalled) in I940, as described by Samuel Lubell in his The Future of American Politics.14

Throughout the country in 1940 , Roosevelt's proportion of the major party vote dropped roughly 7 per cent from 1936. There were twenty counties where his loss exceeded 35 per cent ... Nineteen of these counties are predominantly German-speaking in background.

And these counties were almost entirely rural counties-where, according to the theories of the exclusionists of the I920's, it was easier for immigrants to be integrated, as against the dense immigrant colonies of the cities.

Lubell's book is filled with examples of "ethnic voting." The conclusion is undeniable: if by political integration we mean that immigrant groups should be undifferentiated in their political behavior from other Americans, then they are not politically integrated.

But now we must modify these harsh conclusions. Let us refer again to

${ }^{12}$ See Cart Wittre, The Irish in America cc. I4, 15 (I956).

${ }^{13}$ See, e.g., Walter Mirlis, The Forrestal Diaries 346 (i95x); 2 Harry S. Truman, Memoirs 158 (1956).

${ }^{14}$ LUBELL, op. cit. supra note 9, at 132. 
Randolph Bourne, from whose essay written during World War I we have already quoted. Later in it, he wrote: ${ }^{15}$

The unpopular and dreaded German-American of the present day is a beginning amateur in comparison with those foolish Anglophiles ... . whose reversion to cultural type sees uncritically in England's cause the cause of Civilization, and, under the guise of ethical independence of thought, carries along European traditions which are no more "American" than the German categories themselves.

Are the immigrants so different from the old settlers? Bourne asked. Thirty-five years later, Lubell was to point out that the most interventionist section before our entry into World War II was the South-which was also the section of the country in which the white population was most completely of English origin. ${ }^{10}$

May we, then, absolve the immigrant groups of failing to integrate by pointing out that all groups-even those whose roots go back three hundred years-fail to integrate, in the sense of voting without any concession to the feelings of loyalty and identification aroused by their original homelands? I think it would be an error to stop there and to let it appear that we must accept the idea that ethnic groups, no matter how long in this country, remain identified with their countries of origin. This is only in part true. Not only Germans and Irishmen were isolationist, and not only those of English descent, Jews, and Poles were interventionist. Isolationism and interventionism were primarily political positions, argued in their own terms and in terms of a national American interest-not the interests of ethnic groups. It is, indeed, true that those of certain ethnic backgrounds tended to find the arguments supporting the position favorable to their old homelands more persuasive. But never did the slogan go up, "German Americans-or Anglo-Saxons-you must defend your homelands." This was a surreptitious and scarcely acknowledged motive. Overriding all was the sense of a common national interest, and the arguments in this debate, and in other debates in which the interests of the homelands of immigrant groups have been involved, dealt primarily and almost exclusively with national and not group interests.

In domestic politics, we find in America the most unashamed appeals to special group interests-but groups defined in economic terms. No respectable party or politician in America appeals openly to the interest of an ethnic group in favor of its homeland. The appeal to an ethnic group is couched in national terms; all groups accept the national interest as overriding. Is anything more striking than the fact that no representative Jewish voice was raised in this country proposing concessions by the United States to save the Jews of Europe while they were being slaughtered by Hitler? And this at a time when many Jews knew-or had reason to believe-that American dollars could save many thousands? Nothing can be done about group feelings; in this sense, one may say immigrant groups, or parts of them, may not be integrated after three and four and more generations. But even the first generation

15 Bourne, op. cit. supra note 8 , at 273 .

${ }^{10}$ LUBELL, op. cit. sipra note 9 , at 133 . 
accepts the fact that any action in favor of the old nation must be legitimized by showing that it also forwards American national interests. Thus, Poles who are anti-Communist form part of the large majority of the American population that is anti-Communist, and pro-Israel Jews argue that a strong Israel is an aid to American foreign policy. It is in this sense that we can say that the immigrant groups are politically integrated. ${ }^{17}$

\section{IV}

I have proceeded from the simple to the more complex and have now arrived at the most complicated aspect of the problem of integration, cultural integration. Rather than defining cultural integration, I have taken the easy way out of pointing to nations that clearly have a culture (and I use the term to apply both to "high culture" and the ordinary way of life of the people)-and then saying that American culture, it strikes me, is not of the same type. And I have also suggested that it was the threat to the sense of an integrated American culture that led to the exclusionist legislation of the twenties.

This is, admittedly, a more charitable interpretation of that legislation than most of its critics have allowed in the past. Looking at the irrational hatreds of the $\mathrm{Ku}$ $\mathrm{Klux} \mathrm{Klan}$ and deadly consequences of racist thinking in Germany, it has not been easy to see in the exclusionism of the 1920's anything so positive as a defense of culture. Was not American culture different from other cultures-indeed, based on difference and heterogeneity? How could exclusionism have been a defense, rather than an attack on basic American principles?

So we see it today; and yet, in the beginning, the United States was a nation very much like England or France-that is, a nation most of whose people were drawn from a common racial pool (however mixed racially that pool might have been), speaking the same language, holding similar values, having similar experiences. In 1790 , it has been estimated, ${ }^{18}$

. . 82.I per cent of the whites . . . in the United States were of English lineage, an additional 7 per cent were of Scottish descent, r.9 were Irish. In other words, about 9I per cent of the whites were from, or descendants of people from, the British Isles. Most of the remainder were German and Dutch ....

similar to the others, we might point out, in religion. Immigration did not hit I0,000 a year until I825, did not pass 50,000 until I832, and hit roo,000 for the first time in $1842^{19}$ The Revolutionary War, the War of 1812, and the Mexican War were fought by a homogeneous nation, overwhelmingly English in origin. Toqueville had no sense of a nation of nations, a mosaic of peoples. It was only after the middle of the I840's that America began to be transformed from a country

\footnotetext{
${ }^{17}$ Elsewhere in this symposium, the political impact of immigration is more extensively considered. See Fuchs, Some Political Aspects of Immigration, infra 270-83.

${ }^{18}$ Kiser, supra note Io, at 118.

${ }^{10}$ See Bernard, op. cit. supra note 3, at 299.
} 
as homogeneous as Australia and New Zealand to something like what the United States is today.

When the founding fathers talked of America as a land of refuge, they envisaged the refugees as coming from no very distant clime-they thought of them escaping from European monarchs and easily becoming part of the very specific nation America had become. It would not have been simple to define its cultural characteristics-it is never easy to define a culture. And yet, if we think of the America of the I830's and 1840's, we do have a sense of an individual and distinct nation, with a particular physiognomy, looser, to be sure, than that of France and England. By the time of the Civil War, the heterogeneity of the United States had been radically heightened. The representatives of many nations fought under the Union flag, the farmlands of the Midwest were becoming largely German and Scandinavian, the great cities of the Northeast were becoming largely Irish. After the Civil War, immigration began to lose its character-for most thinking Americans-as the salutary contribution of the United States to the freedom of the world, as the escape valve we provided for oppressed patriots of other lands. By the I870's, the most powerful advocates of free and unrestricted immigration were the business interests, ${ }^{20}$ activated only by a desire for cheap labor. The native-American working class was its most consistent opponent. ${ }^{21}$ And the intellectuals of New England, who had done most to create a distinctive American culture (in the sense now of "high culture"), were beginning to feel the discomfort before the rising tide of immigration that was to make them, within the next two decades, opponents of immigration. As one of them wrote: $:^{22}$.

We are submerged beneath a conquest so complete that the very name of us means something not ourselves. . . I I feel as I should think an Indian might feel, in the face of ourselves that were.

By the time World War I broke out, it was clear to most thinking people that it was no longer possible to believe that the vast numbers of immigrants that had entered since the beginning of the century (almost 13,000,000 between 1900 and I9I4!) had not radically changed America. As I suggested above, industrialism, in its radical reconstruction of American society and even landscape, had perhaps more to do with the change than the vast numbers of immigrants. But they too had something to do with it. They transformed the great cities, altered the character of important countrysides, made many Americans feel they were living in a foreign country, one not their own. What, one may say, did it matter who worked in "the dark satanic mills"? Didn't industrialism create "two nations" out of homogeneous England? But it was different in America. I think of the girls working in the first textile factories in Lowell, whose working instructions included regula-

${ }^{20}$ See John Higham, Strangers in the LAND 16 (1956).

${ }^{22}$ See id. at $45-50$.

${ }^{29}$ As recounted in Horace M. Kallen, Culture and Democracy in the United States 93 (1924) (Quaere: Is it Henry Adams?) 
tions about going to church and leading proper, moral lives. Their employers believed (perhaps wrongly) that they understood their employees completely and, in this understanding, could presume to regulate their lives. And then I think of a working class of foreigners, speaking a strange language, following strange customs, who had become quite incomprehensible to native employers. Something in the two pictures-admittedly not everything-is explained in the shift from a native to a foreign working class.

Or consider the impact of immigration on high culture. Why was there so radical a break with the genteel tradition in America between Igoo and 1920? Why did the young radical writers coming to Greenwich Village in this period assume that American culture did not exist-or, if it did exist, was bloodless and worthless and would have to be created anew? The break was surely not so radical in England and France, nor do we feel today that the American writers and philosophers of the end of the nineteenth century were so inferior to those of England and France as to have occasioned so sharp an attack.

The answer, to my mind, is that the new America of the early twentieth century was in such large measure a foreign America that the old representatives of high culture could not understand it. The new radical intelligentsia thought of the stockyards of Chicago, the immigrant farmers of the Midwest, the radical (and largely foreign) workers of the heavy industries-and felt something had to happen to American culture so that it could in some way reflect the impact of these new groups. If the young writers became socialists, they came in contact with a movement which in America had to be-and was-largely foreign, led by foreign intellectuals, appealing to foreign-born workers.

Out of this recognition came the most stimulating writing on the impact of immigrants on American culture that we have yet had-Randolph Bourne's essay on "Trans-National America," and Horace Kallen's essays in Culture and Democracy in the United States. Out of the idea-and it was an idea held by native-born as well as immigrant intellectuals-that American culture did not exist (what they meant was that the culture adequate to the new America created by immigration and industrialism did not exist), came the notion that a new culture had to be created. Bourne spoke of a cosmopolitan culture in which Americans would hold a dual citizenship spiritually - to the culture of their immigrant group and native land, and to a larger American culture. Kallen, somewhat more radically, conceived of a situation in which the larger American culture would be something of a broker between the cultures of immigrant and ethnic groups and have not much character of its own-aside from tolerance.

Both writers were wrong, I think, in exaggerating the strength of the cultures of the native groups. They were right, however, in seeing that the American culture that had been created by the descendants of English immigrants was undergoing large changes. Today, we can understand that change better than could those writers of forty years ago. 
What has changed, primarily, is that the sense of homogeneity that is a natural part of most great cultures we have known up to now has been replaced by a pervasive sense of heterogeneity. Mark Twain, for example, could, when he wrote about childhood, assume a general measure of understanding in his audience. He could assume his prejudices and experiences would be familiar to them. The same writer writing today would have to treat these prejudices and experiences as "local color." He would approach them with a somewhat different irony-he would be aware of that large public for whom what he was saying was quaint, or, on a higher level, served to increase "understanding." I put the word in quotes because I wish to use it in the sense in which it is so often used in America today-that is, as a synonym for tolerance.

The important American books of the last forty years are books that in large measure have the character of sociological explorations of American subcultureswe are so various that a good part of the job of culture is simply to explain ourselves to each other. A hundred years ago, there were three American subculturesNew England, the South, and the West-and all three shared a good deal in common. Today there are scores. There is the life of the big cities, of the urban Negro and the rural Negro, of the Jews and the Italians, of the midwestern farmer, of the city middle classes and the self-conscious intellectuals. There are all the various milieux that are explored in American fiction, and the word "explored" is the right one, for to many of the readers of this fiction, these milieux are as strange as a foreign country.

Our loss of the sense of homogeneity that characterizes almost every great culture has also meant the loss of a sense of intimacy in the way in which our leading cultural figures express themselves. When an American writer refers to the deeply personal, he also becomes deeply obscure. Nothing is so general about our intimate experience to be taken for granted. When an American writer expresses his prejudices, he cannot expect to find a large and understanding community that shares them, or, if it does not share them, is tolerant of them, as it would be tolerant of the peccadilloes of a member of the family. If he is so bold as to adopt the tone of the intimate gathering in public, he must expect to be rapped on the knuckles and be told by publishers, reviewers, and defense organizations (and almost every group has one or more) not to rock the boat. And, as a matter of fact, he generally does not. All he does is informed by the feeling that in the United States, only very general values are expressed without difficulty. And so American culture is divided between the public and-also-platitudinous, and the intensely personal and obscure. The tone of voice that is so often taken for granted in England and France-the great writer expressing his crochets and peculiaritiesdoes not exist in America. If one wishes to be that peculiar, one becomes, willynilly, a member of the avant-garde, restricted to a special audience. The great writers express only public, proper values. 
In the last few paragraphs, I have only suggested some of the consequences for American culture of the make-up of the American people. I have not discussed other consequences, rather better known, that fall under the heading of "contributions" of immigrant groups. ${ }^{23}$ It is well known that ethnic groups affect the content of American culture at all levels, from the highest to the lowest, introducing new art forms (like types of jazz and musical comedy) as well as new food. We have been concerned here with the question of whether there has been an impact on the over-all form of culture, and I have suggested there has. This impact derives not from the existence of immigrant subcultures, as certain writers once thought it would, for these subcultures decline very rapidly and have no future. It comes from the brute presence of infinite social heterogeneity, which destroys the sense of intimacy and assured understanding that have characterized most of the other great cultures we know.

Have the immigrant groups become culturally integrated into America? The answer we have proposed transcends the frame of this question. They have changed American culture: within this changed culture, they, as well as the long-settled groups of English, Irish, and Germans, are now quite at home.

\section{V}

Many writers who favor the historical policy of free immigration and who would like to see it or something close to it restored write as if immigration has had no effect on America except to make it bigger, better, and stronger-more of the same. I think it betrays a lack of a sense of history to think that the greatest migration in history has had only that as a consequence. True, America was made bigger, better, and stronger. It was also made different.

I would not undo that difference. But it is reasonable to suggest that one of the necessary decisions that must precede the formulation of a national policy on immigration is whether we want to become even more different or are satisfied with what we are. In I92I, the American people decided they wanted to stop. America as it was constituted either satisfied them or, if it did not, they did not think they would be happier with the changes that continued heavy immigration would introduce. Nations have rarely been faced with the problem of deciding their ethnic make-up, but the United States was. I think the racist thinking that accompanied that decision was reprehensible. The decision itself, however, one can understand. America had decided to stop the kaleidoscope and find out what it had become.

${ }^{23}$ This aspect of the subject is considered in greater detail in another article of this symposium. See Burma, Some Cultural Aspects of Immigration: Its Impact, Especially on Our Arts and Sciences, infra $284-98$. 